\title{
NIEOSIĄGALNA JEDNOŚĆ, CZYLI DWA WZORCE EKUMENIZMU*
}

0. Wszyscy teologowie chrześcijańscy zgodnie twierdzą, że największym dobrem, jakie człowiek może osiągnąć, jest zbawienie. Wszystkie chrześcijańskie Kościoły i Wspólnoty wyznaniowe za swą powinność i zadanie uznają prowadzenie ludzi do zbawienia. Jednak fakt wielości tych wspólnot, różniących się w kwestiach dogmatycznych i wzajemnie skonfliktowanych, jawi się jako zaprzeczenie postawy ewangelicznej i rodzi wątpliwości, czy ich misja może być skuteczna. Od dawna więc podejmowano wysiłki z intencją zjednoczenia wszystkich chrześcijan w jednym Kościele powszechnym; współcześnie określa się tego rodzaju działania mianem ekumenizmu. Obecny ruch ekumeniczny zrodził się w początkach XIX wieku w Kościołach protestanckich i anglikańskich, a przez Kościół katolicki od początku traktowany był jako rezultat postawy teologicznie błędnej. Ówczesne stanowisko katolickie wyraził papież Pius XI w encyklice Mortalium animos, wydanej 6 stycznia 1928 roku$^{1}$. Jak w wielu innych kwestiach pastoralnych, tak i w tej zasadniczą zmianę przyniosły ustalenia Drugiego Soboru Watykańskiego; poświęcony ekumenizmowi Dekret Unitatis redintegratio, podpisany 21 listopada 1964 roku przez papieża Pawła VI, dał nową wy-

* Tezy artykułu dyskutowane były ze słuchaczami IV roku Studiów Doktoranckich na wydziale Filologicznym Uniwersytetu w Białymstoku w roku akademickim 2014/15.

${ }^{1}$ Zob. Pius XI, Mortalium animos - O popieraniu prawdziwej jedności religii, Warszawa 2001. 
kładnię stanowiska katolickiego ${ }^{2}$. Te dwa dokumenty przedstawiają w istocie dwa wzorce ekumenizmu, które wprawdzie nie pozostają do siebie w sprzeczności, ale są oba niemożliwe do zrealizowania. Ta niemożliwość ma charakter zasadniczy, jest więc nieusuwalna - a bierze się z metafizycznej natury tego świata i z natury człowieka jako bytu do tego świata należącego.

1. Teologicznym uzasadnieniem ekumenizmu są słowa Jezusa z Ewangelii według św. Jana, będące fragmentem Jego modlitwy za przyszły Kościół: „A nie tylko za nimi proszę, ale i za tymi, którzy przez słowo ich uwierzą we mnie; aby wszyscy byli jedno, jako ty, Ojcze, we mnie, a ja w tobie, aby i oni w nas jedno byli, aby uwierzył świat, że ty mię posłałeś. A ja chwałę, którą mi dałeś, dałem im, aby byli jedno, jak i my jedno jesteśmy" 3 . Jest $\mathrm{w}$ tych słowach wyrażone jednoznacznie pragnienie, "aby wszyscy byli jedno", ale rozumienie tej jedności nie zostało podane wprost, wymagają więc one stosownej interpretacji. Na rozwój teologii chrześcijańskiej można spojrzeć jako na stopniowe precyzowanie sensu i wzbogacanie treści pojęcia jedności. Po rozłamie z 1054 roku rozwój ten przebiegał odmiennie w chrześcijaństwie wschodnim i w chrześcijaństwie zachodnim, nadto zaś prawie pięćset lat później doświadczeniem wstrząsowym dla Kościoła zachodniego stała się schizma protestancka. Swoistą „reakcją obronną" przeciwko ruchom reformacyjnym były ustalenia Soboru Trydenckiego (1545-1563) precyzujące formę i treść dogmatów Kościoła katolickiego; faktycznie, wyznaczały one warunki konieczne wspólnoty wiary. W całkowitej zgodności $\mathrm{z}$ duchem tradycji Trydentu oceny działań ekumenicznych dokonał papież Pius XI w encyklice Mortalium animos.

Encyklika jako punkt wyjścia przyjmuje oczywiście rozumienie Kościoła katolickiego jako Mistycznego Ciała Chrystusa, ale w kontekście rozważania kwestii ekumenizmu zwraca uwage na jego wymiar społeczny. Podkreśla się, że "Chrystus ustanowił swój Kościól jako społeczność, z istoty swej na zewnątrz widomą, aby pod kierownictwem jednej głowy [...], przez nauczanie żywym słowem [...] i przez udzielanie sakramentów [...] kontynuowała w przyszłości dzieło odkupienia ludzkości"4. Takie ujęcie prowadzi do bardzo ważnego wniosku praktycznego: „Skoro to mistyczne ciało Chry-

2 Zob. Dekret o ekumenizmie "Unitatis redintegratio", [w:] Sobór Watykański II. Konstytucje, dekrety, deklaracje, Poznań 1968, s. 203-218. W cytowaniach podajemy wskazanie na punkty Dekretu.

${ }^{3}$ J 17,20-22; w przekładzie Jakuba Wujka. Ten i dalsze cytaty za: Pismo Święte Starego i Nowego Testamentu, Kraków 1962.

4 Pius XI, Mortalium animos, op. cit., s. 9. 
stusa, Kościół, jedno jest [...], spojone i złączone [...] jako ciało fizyczne, bardzo niedorzecznym człowiekiem okazałby się ten, kto by chciał twierdzić, że ciało mistyczne Chrystusa może się składać z odrębnych, od siebie oddzielonych członków" ${ }^{\prime \prime}$. Kościół katolicki nie jest więc tylko wspólnotą wiary, lecz także fizyczną (społeczną) przestrzenią, w której wspólnota wiary może się realizować. Wszelka jedność może być zatem realizowana $\mathrm{w}$ ramach Kościoła katolickiego, nie może zaś być rozumiana tylko jako jedność z Kościołem katolickim. Błąd ekumenistów polega właśnie na rozumieniu jedności jako związku wspólnot chrześcijańskich i na niemożności dostrzeżenia, że tak pojmowana jedność mogłaby realizować się jako związek o charakterze wspólnoty politycznej, nie zaś wspólnoty wiary. Prowadzi to w istocie do tezy, że jeden Kościół, będący Mistycznym Ciałem Chrystusa, jest jedynie postulatem do zrealizowania; jedności jeszcze nie ma, dopiero należy do niej dojść, czyli spełnić życzenie Chrystusa, „aby wszyscy byli jedno”. Różnicę stanowisk można więc wyrazić następująco: według ekumenistów jedność Kościoła Chrystusowego nigdy nie istniała i nadal nie istnieje, według Piusa XI natomiast jedność ta istnieje od czasów apostolskich. Z innego punktu widzenia ujęta, jest to różnica między przekonaniem ekumenistów, że Kościół jest zbiorowością wielu odrębnych wspólnot, a przeświadczeniem Piusa XI, że poszczególne wspólnoty chrześcijańskie są rezultatem kolejnych aktów odchodzenia od jednego powszechnego Kościoła Chrystusowego.

Przy takim rozumieniu zagadnienia Pius XI konsekwentnie uznaje, że właściwie pojmowane działanie ekumeniczne może polegać na staraniach zmierzających do powrotu w przestrzeń wiary jedynego Kościoła tych, którzy od niego odpadli. „Jasną rzeczą więc jest [...], dlaczego Stolica Apostolska swym wiernym nigdy nie pozwalała, by brali udział w zjazdach niekatolickich. Pracy nad jednością chrześcijan nie wolno popierać inaczej, jak tylko działaniem $\mathrm{w}$ tym duchu, by odszczepieńcy powrócili na łono jedynego, prawdziwego Kościoła Chrystusowego, od którego kiedyś, niestety, odpadli" ${ }^{\prime}$. Oczywiście, warunkiem koniecznym takiego powrotu musi być uznanie władzy papieskiej. „W tym jednym Kościele Chrystusa jest i pozostaje tylko ten, kto uznaje autorytet i władzę Piotra i jego prawnych następców, słuchając i przyjmując ją"7. Pius XI wskazuje, że ekumeniści gotowi są uznać prymat papieski jedynie jako honorowy, jeśli zaś miałaby się z tym wiązać jakaś władza, to jako uprawnienie pochodzące $\mathrm{z}$ woli wiernych, a nie $\mathrm{z}$ prawa Boskiego ${ }^{8}$. W tym kontekście zakaz oficjalnych kontaktów katolików

\footnotetext{
${ }^{5}$ Ibidem, s. 16.

${ }^{6}$ Ibidem.

7 Ibidem, s. 17.

8 Zob. ibidem, s. 11.
} 
z nie-katolikami musi być odczytywany jako wyrażający mocne przekonanie, że wszyscy, którzy odeszli od Kościoła katolickiego, winni do niego powrócić mocą samego światła prawdziwej wiary wyznawanej przez ten Kościół.

Wielość i różnorodność wspólnot chrześcijańskich jest zarazem wielością i różnością wyznawanych treści wiary. Ekumeniści, dążąc do jedności, której jeszcze nie ma, dążą więc tym samym do utworzenia jednej, wspólnej reguły wyznania, która zjednoczyłaby wszystkich chrześcijan w przestrzeni wiary. Pius XI stawia retoryczne pytanie, czym miałaby być ta postulowana wspólnota wiary. $W$ tej perspektywie osiągnięcie jedności byłoby równoznaczne z osiągnięciem jednorodnego i jednolitego rozumienia dogmatów wiary. Zdaniem Piusa XI, jest to możliwe jedynie na drodze relatywizacji prawd dogmatycznych; ekumeniści „nie uważają prawdy dogmatycznej za absolutną, lecz za relatywną, to znaczy za zmienną według rozmaitych miejscowych i czasowych potrzeb, jakoby ona nie stanowiła treści niezmiennego objawienia, lecz przystosowywała się do życia ludzkiego" 9 . Postawę taką Pius XI oczywiście jednoznacznie potępia, jak też zdecydowanie odrzuca możliwość rozróżnienia między zasadniczymi (czyli takimi, które muszą być przyjęte przez wszystkich) a niezasadniczymi (czyli pozostawionymi do swobodnego uznania wiernych) punktami wiary. "Nadnaturalna cnota wiary ma swą przyczynę formalną $\mathrm{w}$ autorytecie objawiającego Boga i nie dopuszcza podobnej różnicy"10.

Zadaniem urzędu nauczycielskiego Kościoła jest jednoznaczne określanie artykułów wiary po to właśnie, aby ich treść była właściwie rozumiana przez wiernych lub aby ujęta została w sposób jaśniejszy i głębszy. Dzięki temu zapobiega się błędom, jak też wydobywa się na jaw prawdy zawarte w Objawieniu w sposób ukryty. Papież podkreśla przy tym, że urząd nauczycielski Kościoła jest powołany do strzeżenia i wyjaśniania prawd objawionych, nie zaś do wprowadzania prawd nowych. "To nadzwyczajne wykonywanie urzędu nauczycielskiego nie oznacza jednak, by wprowadzano jakąśs nowość. Przez to nie wprowadza się też niczego nowego do tej ilości prawd, które zawarte są, domniemanie przynajmniej, w skarbie Objawienia, przekazanym Kościołowi przez Boga. Przez to wyjaśnia się tylko prawdy, które dotąd mogły w oczach wielu uchodzić za mgliste, lub też stwierdza się prawdy wiary, którym uprzednio ten czy ów przeczył"11.

\footnotetext{
${ }^{9}$ Ibidem, s. 14-15.

${ }^{10}$ Ibidem, s. 15.

${ }^{11}$ Ibidem, s. 15-16.
} 
Stanowisko Piusa XI jest jednoznaczne i nie dopuszcza żadnych interpretacji rozszerzających. Kościół rzymskokatolicki to jedyny Kościół utworzony przez Jezusa, a zatem jedyny posiadający pełnię prawdy; w konsekwencji więc powracanie do jedności może polegać jedynie na powracaniu poszczególnych osób lub wspólnot odłączonych, czyli na ich nawracaniu się. Wszelkie inne podejście wymagałoby bowiem odrzucenia przez Kościół rzymskokatolicki przekonania o wyłącznym posiadaniu prawdy. Różnice dogmatyczne między katolicyzmem a pozostałymi odłamami chrześcijaństwa ujmowane są w opozycji dychotomicznej, przeciwstawnej sobie i niedopuszczającej interpretacji uzgadniającej. Przykładowo, albo wierzy się, że w sakramencie Eucharystii obecny jest Chrystus prawdziwie i rzeczywiście, albo przyjmuje się, że jest obecny jedynie przez wiarę czy w sposób symboliczny; nie można kwestii tej zinterpretować tak, aby rozbieżne stanowiska uzgodnić, nie można przyjąć jakiejś pośredniej treści dogmatu. Podobnie: albo Msza św. jest uobecnieniem Ofiary Krzyżowej, albo jest tylko wspomnieniem Ostatniej Wieczerzy; jakakolwiek interpretacja pośrednia jest niedopuszczalna. Tak więc, w sferze prawd dogmatycznych Kościół rzymskokatolicki nie musi, a wręcz nie może się zmienić, ci natomiast, którzy się od niego odłączyli, muszą zrozumieć swoje błędy.

2. Soborowy Dekret o ekumenizmie Unitatis redintegratio punktem wyjścia również czyni słowa Jezusa wyrażające Jego pragnienie, „aby wszyscy byli jedno", ale podkreśla przy tym, że fundamentem tej jedności jest sakrament Eucharystii, „który oznacza i sprawia jedność Kościoła” (p. 2). Tak samo też zakłada pierwotną jedność Kościoła Chrystusowego, która dopiero z czasem ulegać zaczęła osłabianiu. W Dekrecie uznaje się jednak, że nie bez winy są nie tylko ci, którzy od Kościoła odchodzili, lecz także ci, którzy w nim pozostali. Takie uznanie własnej winy pozwala inaczej spojrzeć na tych, których chce się znów złączyć w jedność. „Tych zaś, którzy obecnie rodzą się w takich Społecznościach i przepajają się wiarą w Chrystusa, nie można obwiniać o grzech odłączenia. A Kościół katolicki otacza ich braterskim szacunkiem i miłością" (p. 3). Nie pomijając różnic, nacisk zdaje się położony na to, co łączy, a mianowicie zachowywanie wielu wspólnych treści wiary, „których moc pochodzi z samej pełni łaski i prawdy, powierzonej Kościołowi katolickiemu" (p. 3).

Dekret składa się z trzech części: w pierwszej wyłożone zostają katolickie zasady ekumenizmu, w drugiej ukazane zasady praktyki ekumenicznej, w trzeciej zaś wyjaśniony stosunek Kościoła katolickiego do innych Kościołów i Wspólnot kościelnych. Wyłożenie zasad ekumenizmu poprzedzone zostało znamiennym apelem do wiernych: „obecny Sobór zachęca wszyst- 
kich wiernych Kościoła katolickiego, by rozeznając znaki czasu, pilnie uczestniczyli w dziele ekumenicznym" (p. 4). Ruch ekumeniczny definiowany jest jako „działalność oraz przedsięwzięcia zmierzające do jedności chrześcijan, zależnie od różnych potrzeb Kościoła i warunków chwili" (p. 4). Dekret wymienia dwa rodzaje owej działalności. Pierwszy jest obowiązkiem wszystkich wiernych, a polega na staraniach, aby wystrzegać się używania słów, wypowiadania opinii i podejmowania czynów, które nieprawdziwie, krzywdząco, nieżyczliwie czy niesprawiedliwie odnoszą się do „braci odłączonych", a przez to utrudniają wzajemne stosunki. Drugi jest powinnością teologów, a polega na podejmowaniu "dialogu” z teologami innych wyznań chrześcijańskich, by dzięki temu uzyskiwać bliższe poznanie prawdy i lepsze zrozumienie stanowisk. Zarazem jednak podana jest $\mathrm{w}$ istocie sugestia, że ta działalność ekumeniczna teologów musi być włączona w kontekst całej wspólnoty katolików, którzy swym nastawieniem ekumenicznym ułatwiają możliwość dialogu ekumenicznego. Sobór zwraca się do ogółu wiernych: „Wierni Kościoła katolickiego powinni bez wątpienia w pracy ekumenicznej troszczyć się o odłączonych braci, modląc się za nich, użyczając im wiadomości o sprawach Kościoła, i pierwsi powinni wychodzić im naprzeciw" (p. 4). Tym samym więc aktywna postawa ekumeniczna staje się powinnością katolików, którzy całym swym życiem mają dawać świadectwo o tym, czego nauczał Chrystus, a co przekazali Apostołowie. Dekret stwierdza przy tym wyraźnie, że świadectwo autentycznej wiary mogą dawać także bracia odłączeni, a katolicy powinni to uznać ku własnemu zbudowaniu. „Słuszną i zbawienną jest rzeczą uznać Chrystusowe bogactwa i cnotliwe postępowanie w życiu drugich, którzy dają świadectwo Chrystusowi, czasem aż do przelania krwi" (p. 4).

Jeśli chodzi o sposoby wprowadzania ekumenizmu w życie, to Dekret już na samym początku tej części rozważań (p. 5) kolejny raz wskazuje, że troska o jedność jest obowiązkiem całej wspólnoty katolickiej - tak wiernych, jak i ich pasterzy - a realizować się ma zarówno w życiu codziennym, jak i w badaniach teologicznych. Teraz wskazane zostaje nadto, skąd bierze się konieczność praktyczna (jeśli tak można powiedzieć) dążenia do jedności, mianowicie z potrzeby dokonywania permanentnej reformy. „Do pielgrzymującego Kościoła kieruje Chrystus wołanie o nieustanną reformę, której Kościól, rozpatrywany jako ziemska i ludzka instytucja, wciąż potrzebuje" (p. 6). Wyjaśnia się następnie, że owa nieustanna reforma dotyczyć ma rozumienia, wyrażania i przestrzegania zasad obyczajowych, kościelnego ustawodawstwa oraz samej doktryny. Poczyniono przy tym ważne zastrzeżenie, iż sposób wyrażania doktryny „należy stanowczo odróżnić od samego depozytu wiary" (p. 6). 
Warunkiem koniecznym postulowanej permanentnej reformy jest stała przemiana duchowa: „Nie ma prawdziwego ekumenizmu bez wewnętrznej przemiany" (p. 7). Z dalszych wywodów można wnosić, iż ta przemiana polegać ma na otwarciu się $\mathrm{w}$ duchu miłości na braci odłączonych, zgodnie ze wskazaniem św. Pawła Apostoła, by chrześcijanie odnosili się do siebie "z wszelką pokorą i cichością, z cierpliwością, znosząc się wzajemnie w miłości" (Ef 4,2). Odnosi się to do wszystkich wiernych, ale w szczególny sposób do kapłanów. Zarazem wierni pamiętać powinni o słowach św. Jana, że przed Bogiem wszyscy jesteśmy grzesznikami: „Jeślibyśmy powiedzieli, żeśmy nie zgrzeszyli, kłamcą go czynimy i nie ma w nas jego słowa" (1J 1,10). Konsekwentnie ma to skłaniać do wzajemnego odpuszczenia win: "Z pokorną więc prośbą zwracamy się do Boga i do odłączonych braci o wybaczenie, jako i my odpuszczamy naszym winowajcom" (p. 7). Dekret wyraźnie stwierdza, że tak pojmowaną przemianę "należy uznać za duszę całego ruchu ekumenicznego" (p. 8), i nazywa ją "ekumenizmem duchowym". Na tej podstawie dopuszcza się, a nawet zaleca wspólne modlitwy z braćmi odłączonymi, oczywiście z wykluczeniem działań mogących naruszyć sferę dogmatyczną. Wszystkie tego rodzaju działania mają prowadzić do poznania stanowisk niekatolików, dzięki czemu będzie można „w odpowiedniejszy sposób wyłożyć im naszą wiarę" (p. 9). W tym kontekście bardzo dużą wagę przywiązuje się do takiego wykładu wiary katolickiej, aby była należycie rozumiana przez niekatolików. Jednocześnie wskazuje się, że konieczne jest przy tym uwzględnianie „porządku czy «hierarchii» prawd w nauce katolickiej, ponieważ różne jest ich powiązanie z zasadniczymi podstawami wiary chrześcijańskiej" (p. 11). Za fundament dogmatyczny działań ekumenicznych uznaje się wiarę w Trójcę Świętą. „W obliczu wszystkich narodów niech wszyscy chrześcijanie wyznają wiarę w Jednego i Troistego Boga, we Wcielonego Syna Bożego, naszego Pana i Zbawiciela, a wspólnym wysiłkiem we wzajemnym szacunku niech dają świadectwo naszej nadziei, która nie zawodzi" (p. 12).

Wskazania dotyczące praktyki ekumenicznej kończą się zaleceniem podejmowania przez wszystkich chrześcijan wspólnych działań na rzecz rozwoju społecznego. „Współpraca ta, zapoczątkowana już wśród pokaźnej liczby narodów, musi się coraz więcej udoskonalać w tych zwłaszcza krajach, które znajdują się na drodze rozwoju społecznego i technicznego, a to przez docenienie godności osoby ludzkiej, popieranie dobra pokoju, stosowanie Ewangelii do życia społecznego, rozwój wiedzy i sztuki w duchu chrześcijańskim czy też stosowanie wszelkich środków zaradczych przeciw niedostatkom naszego wieku, takim jak głód i klęski, analfabetyzm i nędza, brak mieszkań i nierówny podział dóbr" (p. 12). Tak więc dążenie do jedno- 
ści wszystkich chrześcijan realizować się ma nie tylko w płaszczyźnie duchowej, ale także w płaszczyźnie społecznej.

Jeśli chodzi o stosunek Kościoła katolickiego do innych Kościołów i Wspólnot kościelnych, to Dekret czyni zasadnicze rozróżnienie między Kościołami Wschodnimi a Kościołami i Wspólnotami, które odłączyły się od Stolicy Rzymskiej w następstwie reformacji. W odniesieniu do tych pierwszych podkreśla się, że głoszą one „podstawowe dogmaty chrześcijańskiej wiary o Trójcy Świętej i o Słowie Bożym, które przyjęło ciało z Maryi Dziewicy" (p. 14), posiadają bogate tradycje życia wewnętrznego, jak też wspaniałą liturgię. Sobór uznaje prawo Kościołów Wschodnich do „kierowania się własnymi normami (disciplina), jako bardziej zgodnymi z charakterem swoich wiernych i bardziej przydatnymi dla dobra ich dusz" (p. 16). Co więcej, Sobór uznaje tę zasadę za "wstępny warunek przywrócenia jedności” (p. 16). Na podstawie powyższych ustaleń w Dekrecie sformułowane zostały trzy zalecenia praktyczne. Po pierwsze, ponieważ Kościoły te posiadają prawdziwe sakramenty, w szczególności kapłaństwo i Eucharystię, to „pewien współudział w czynnościach świętych (communicatio in saris), w odpowiednich okolicznościach i za zgodą kościelnej władzy, jest nie tylko możliwy, ale i wskazany" (p. 15). Po drugie, ponieważ Kościoły te pielęgnują głęboką duchowość, zatem ,jest bardzo wskazane, by katolicy dużo częściej sięgali po te duchowe bogactwa Ojców wschodnich, które wznoszą człowieka całkowicie ku kontemplacji rzeczy Bożych" (p. 15). Po trzecie, ponieważ w Kościołach tych zachowało się wielkie bogactwo liturgiczne, więc katolicy powinni uświadomić sobie, że „dla wiernego strzeżenia pełni tradycji chrześcijańskiej i dla pojednania chrześcijan wschodnich z zachodnimi niesłychanej wagi jest zapoznanie się, uszanowanie, poparcie i podtrzymywanie przebogatej spuścizny liturgicznej i ascetycznej Wschodu" (p. 15).

Dekret soborowy wyraża więc duży optymizm co do możliwości zjednoczenia obu wyznań. Optymizm ten zdaje się opierać na niewyrażonym jawnie, ale obecnym implicite przeświadczeniu, że przyczyną rozłamu były głównie historycznie uwarunkowane czynniki polityczne, nie zaś istotne rozbieżności doktrynalne. Dlatego bardzo mocna jest zachęta do działań w kierunku przywrócenia jedności. „Jeśli się poprze to dzieło całą duszą, święty Sobór ufa, że po usunięciu dzielącej Zachodni i Wschodni Kościół przegrody nastanie w końcu jedno mieszkanie, osadzone mocno na węgielnym kamieniu, Jezusie Chrystusie, który z dwojga uczyni jedno" (p. 18). Nie mówi się jednak wprost, czym jest owa „przegroda” między obu Kościołami ${ }^{12}$.

$12 \mathrm{~W}$ podstawowym tekście łacińskim użyto słowa paries, czyli „,mur”, „ściana”. 
W odniesieniu do Kościołów i Wspólnot powstałych z rozłamów w czasach nowożytnych Dekret wyraża ufność, że chociaż nie u wszystkich z nich pojawiło się pragnienie jedności, to przecież "stopniowo wzrastać będzie u wszystkich zmysł ekumeniczny i wzajemny szacunek" (p. 19). Przede wszystkim jednak Dekret przyznaje wprost, że przyczyną utrwalenia się rozłamów są nie tyle czynniki polityczne, co względy doktrynalne. „Trzeba jednak przyznać, że między tymi Kościołami i Wspólnotami a Kościołem katolickim istnieją rozbieżności wielkiej wagi, nie tylko na podłożu historycznym, socjologicznym, psychologicznym i kulturowym, lecz głównie w interpretacji prawdy objawionej" (p. 19). Dlatego właśnie w Dekrecie podkreśla się nie różnice, lecz pewne punkty, które mogą stanowić podstawę dialogu. Dekret wymienia trzy zasadnicze punkty oparcia dialogu ekumenicznego. Pierwszym jest wspólna wiara w Jezusa Chrystusa jako Boga i Pana, jedynego pośrednika między Bogiem a ludźmi. Drugim jest uznanie Pisma Świętego jako objawionego Słowa Bożego. Trzecim zaś przyjmowanie sakramentu chrztu jako wprowadzającego do wspólnoty chrześcijańskiej. Wskazuje się też na chrześcijański sposób życia jako czynnik wspomagający dążenie do jedności.

Zarazem jednak przy każdym z tych punktów sygnalizowane są istotne odmienności ich pojmowania. $W$ odniesieniu do Chrystusa chodzi o różnice pojmowania wcielonego Słowa Bożego i dzieła odkupienia, a w konsekwencji także funkcji Kościoła i roli Maryi w dziele zbawienia. Co do Słowa Bożego, różnice dotyczą zasadniczo innego rozumienia stosunku Kościoła do Pisma Świętego, a sprowadzają się do nieuznawania stanowiska katolickiego, że urząd nauczycielski Kościoła odgrywa specjalną rolę w głoszeniu i wyjaśnianiu pisanego Słowa Bożego. Jeśli chodzi o sakrament chrztu, to Dekret podkreśla, że akt chrztu "sam przez się jest jedynie pierwszym zaczątkiem, jako że całkowicie zmierza do osiągnięcia pełni życia w Chrystusie" (p. 22), tym samym więc chrzest jest wprawdzie elementem jedności wszystkich ochrzczonych, ale z uwagi na istniejące różnice bardziej jest nakazem moralnym dążenia do osiągnięcia jedności pełnej.

Dekret nie ukrywa, że między Kościołem katolickim a Wspólnotami powstałymi po reformacji istnieją głębokie różnice dogmatyczne; zarazem jednak daje wyraz przekonaniu, że mogą one zostać usunięte drogą dialogu. „Pomimo że odłączonym od nas Wspólnotom kościelnym brakuje pełnej jedności z nami, wypływającej z chrztu, i choć w naszym przekonaniu nie przechowały one właściwej i całkowitej rzeczywistości eucharystycznego misterium, głównie przez brak sakramentu kapłaństwa, to jednak sprawując w świętej Uczcie pamiątkę śmierci i zmartwychwstania Pańskiego, wyznają, że oznacza ona życie w łączności z Chrystusem i oczekują Jego chwalebnego 
przyjścia. Wobec tego nauka o Uczcie Pańskiej, o innych sakramentach i kulcie oraz o posługach Kościoła powinna stanowić przedmiot dialogu" (p. 22). Dekret nie wyjaśnia jednak, jak ma się protestanckie rozumienie Uczty Pańskiej do katolickiego rozumienia Mszy świętej.

Dekret przyznaje też, iż „wielu spośród chrześcijan nie zawsze w ten sam sposób pojmuje Ewangelię w dziedzinie moralnej co katolicy i nie przyjmuje tych samych rozwiązań $w$ trudniejszych zagadnieniach dzisiejszego społeczeństwa" (p. 23). Nie podejmuje jednak kwestii, na czym te różnice polegają i jakie są ich konsekwencje. Podkreśla jedynie, iż żywe poczucie wiary owocuje poczuciem sprawiedliwości i szczerą miłością bliźniego, $\mathrm{z}$ tego zaś bierze się swoista jedność w działaniach społeczno-politycznych. „Ta zaś czynna wiara stworzyła pokaźną ilość instytucji dla ulżenia nędzy duchowej i materialnej, lepszego wychowania młodzieży, dla stworzenia bardziej ludzkich warunków życia społecznego i utrwalenia powszechnego pokoju" (p. 23). Można więc domniemywać, iż działalność ekumeniczna realizowana być powinna we wszystkich sferach życia duchowego i materialnego człowieka.

Ojcowie Soboru zdają sobie sprawę, że podjęcie działań ekumenicznych może rodzić pewne zagrożenia. Wprawdzie nie wymieniają ich i nie eksponują, jednak uznają za wskazane przestrzec wiernych przed możliwością pobłądzenia. „Święty Sobór obecny wzywa wiernych do powstrzymania się od wszelkiej lekkomyślności i nierozważnej gorliwości, które by mogły zaszkodzić prawdziwemu postępowi ku jedności. Ich bowiem działalność ekumeniczna nie może być inna jak tylko w pełni i szczerze katolicka, czyli wierna prawdzie, którąśmy otrzymali po Apostołach i Ojcach, i zgodna z wiarą zawsze przez Kościół katolicki wyznawaną, a zarazem zmierzającą do tej pełni, która z woli Pana ma z upływem czasu przydawać wzrostu Jego Ciału” (p. 24). Jednocześnie Ojcowie Soboru mają świadomość, że „ten święty plan pojednania wszystkich chrześcijan w jedności jednego i jedynego Kościoła Chrystusowego przekracza ludzkie siły i zdolności" (p. 24). Dlatego Sobór pokłada swą nadzieję w modlitwie Chrystusa za Kościół i w miłości Boga Ojca do ludzi.

3. Podjęcie kwestii ekumenicznej w obu dokumentach jest uzasadniane Chrystusowym nakazem trwania w jedności. Wspólna jest także podstawa rozważań - rozumienie Kościoła jako Mistycznego Ciała Chrystusa. Jednak odmienny jest punkt wyjścia: w encyklice Piusa XI jest nim ujęcie Kościoła katolickiego w jego wymiarze społecznym, jako społeczności ludzi ochrzczonych, a w soborowym Dekrecie o ekumenizmie ujęcie Kościoła w jego wymiarze duchowym, ujawnianym w sakramencie Eucharystii. Nie 
zachodzi tu oczywiście żadna różnica w pojmowaniu Kościoła jako Ciała Mistycznego, będącego swoistym organizmem duchowym, którego Głową jest Chrystus i którego jedność wyraża się najpełniej w zgromadzeniu Eucharystycznym ${ }^{13}$. Różnica zachodzi natomiast co do praktycznego charakteru przekazu - oba dokumenty adresowane są do wiernych Kościoła katolickiego, ale encyklika Piusa XI skierowana jest do wiernych Kościoła katolickiego jako członków instytucji, w ramach której i wspólnie z którą podążać mają oni wspólną drogą do zbawienia, podczas gdy soborowy Dekret skierowany jest do wiernych Kościoła katolickiego jako wspólnoty dążącej do Boga. Dążenie do zbawienia jest zarazem dążeniem do Boga i odwrotnie, ale na co innego jest tu położony nacisk i zasadniczo inne są konsekwencje tych odmienności ujęć.

Papież Pius XI zwraca się do wiernych jako członków instytucjonalnej zbiorowości kroczącej wspólną drogą ku zbawieniu. Kościół katolicki posiada pełnię prawdy objawionej, a zatem wierność tej prawdzie jest warunkiem koniecznym podążania ku Bogu. I choć nie jest to warunek wystarczający do osiągnięcia zbawienia, jako że konieczne jest poświadczanie tej wierności właściwym postępowaniem $\mathrm{w}$ swym życiu, to jednak zejście $\mathrm{z}$ tej drogi skutkuje potępieniem. To, że inni chrześcijanie mają odmienne poglądy teologiczne, jest ich problemem, nie zaś problemem katolików. Zadaniem wiernych nie są bowiem rozważania nad właściwym sensem dogmatów, lecz niezłomna wiara w słuszność nauczania Kościoła katolickiego i prowadzenie życia zgodnie $\mathrm{z}$ nim. Wedle Piusa XI, ekumenizm to po prostu postawa otwartości na tych, którzy uznając swoje błędy, powrócą na łono Kościoła katolickiego. Papież zdaje się porównywać Kościół katolicki do latarni morskiej, która swym światłem wskazuje zabłąkanym statkom drogę do portu. Latarnia morska nie wychodzi przecież w morze w poszukiwaniu statków to one mają jej wypatrywać, a dostrzegłszy jej światło, bezpiecznie dopłynąć do przystani. Zarazem Pius XI zdaje się zakładać, że wprawdzie wszyscy jesteśmy grzesznikami, ale grzechy katolików nie mogą być usprawiedliwieniem dla tych, którzy od Kościoła katolickiego się odłączyli.

Jeżeli ekumenizm w rozumieniu encykliki Mortalium animos może być wyjaśniany za pomocą obrazu latarni morskiej, to w wyjaśnianiu rozumienia ekumenizmu przez Dekret Unitatis redintegratio przydatny może być, przywołany w samym Dekrecie (p. 6), obraz pielgrzymki. Pielgrzymka jako pewien byt fizyczny to grupa ludzi kroczących wspólną, wyznaczoną drogą do określonego miejsca, świadomych swych motywacji i postawionego sobie celu. Ludzie tworzący tę grupę są zdeterminowani w różnym stopniu, jak

${ }^{13}$ Rozumienie takie pojawia się w listach św. Pawła; zob. w szczególności 1Kor 12,12-13; 27. 
też $\mathrm{w}$ różnym stopniu konsekwentni $\mathrm{w}$ swych działaniach właściwych i w różnym stopniu skłonni do działań niewłaściwych. Zazwyczaj jednak są otwarci na przyjęcie innych osób, które mają chęć przyłączenia się, jak też moga podlegać ich wpływom. Soborowy Dekret o ekumenizmie zwraca się do wiernych nie tyle jako członków instytucjonalnej zbiorowości, lecz bardziej jako do wspólnoty ludzi ochrzczonych idących wspólnie przez życie drogą trudną, na której czyha wiele niebezpieczeństw i łatwo popełnić błąd, ale też właśnie dlatego warto być otwartym na tych, którzy kroczą inną drogą. Nie rezygnując więc z przekonania o posiadaniu prawdziwego depozytu wiary, Dekret soborowy zdaje się dostrzegać przyczynę rozłamów nie tylko po stronie „braci odłączonych", lecz także po stronie katolików, a tym samym przyznaje, że grzechy jednej ze stron w jakiejś mierze usprawiedliwiają, a przynajmniej czynią zrozumiałym postępowanie drugiej strony. Dążenie do jedności musi zatem być oparte na uznaniu wzajemnych win, a ponieważ złe postępowanie $\mathrm{w}$ przestrzeni instytucjonalnej jest między innymi konsekwencją złego rozumienia wzajemnego, stąd konieczne staje się podjęcie wysiłków w celu lepszego wzajemnego rozumienia się. Dlatego wedle Dekretu soborowego ekumenizm to podejmowany przez wszystkich katolików, szczególnie zaś przez teologów, stały wysiłek, by coraz lepiej rozumieć pozostałych chrześcijan, ale także $\mathrm{w}$ odniesieniu do siebie coraz lepiej rozumieć, co to znaczy być chrześcijaninem.

Takie rozumienie ekumenizmu narażone jest na ujawnianie się rozmaitych sprzeczności i niekonsekwencji w przyjmowanych postawach i głoszonym przekazie, których nie mogło być w jednoznacznym stanowisku Piusa XI, wyznaczonym przeświadczeniem o własnej słuszności, artykułowanej także na gruncie dogmatu o nieomylności papieskiej. Na przykład Dekret soborowy wskazuje, że sakrament Eucharystii jest podstawą jedności chrześcijan. Można to odczytywać jako chęć realizacji dążeń do jedności w kontekście czysto teologicznym, z pomijaniem (przynajmniej do momentu osiągnięcia daleko posuniętej zgody) kwestii instytucjonalnych, w tym kwestii prymatu Piotrowego. Zarazem jednak Dekret soborowy zdaje się wskazywać, że osiągnięcie jedności chrześcijan nastąpi nie w rezultacie zrozumienia błędów teologicznych, lecz drogą oddziaływania świadectwa wiary. Nie stawia się przy tym pytania, czy możliwe jest, aby takie świadectwo wiary silniej wystąpiło po stronie braci odłączonych. W tym kontekście należy zauważyć, że wprawdzie w Dekrecie wskazuje się, że sposób wyrażania doktryny "należy stanowczo odróżnić od samego depozytu wiary” (p. 6), ale nie podejmuje się kwestii, jakie mogą być kryteria tego odróżnienia.

Wyrażonemu w Dekrecie pragnieniu osiągnięcia pełnego wzajemnego zrozumienia musi też towarzyszyć pojawianie się obaw, że zbyt mocne 
i jednoznaczne ukazywanie własnego stanowiska w ogóle uniemożliwi dialog. I tak przykładowo w kontekście Trójcy Świętej soborowy Dekret wspomina o Synu Bożym, ale nie wspomina o Duchu Świętym. Być może dlatego, aby nie dotykać zagadnienia będącego jednym z punktów spornych między katolicyzmem a protestantyzmem. Wprawdzie bowiem wiara $\mathrm{w}$ Boga w Trójcy Świętej Jedynego łączy oba wyznania, ale wedle Kościoła katolickiego Duch Święty działa przede wszystkim przez Sakramenty, a wedle Kościołów protestanckich przede wszystkim przez Słowo Boż $\mathrm{e}^{14}$. Innym przykładem potwierdzającym istnienie takich obaw jest wyraźnie obecna w Dekrecie sugestia, że owa „przegroda” między Kościołami Zachodnim i Wschodnim ma charakter polityczny. Można oczywiście domniemywać, że chodzi o tak zwany prymat papiestwa. Jest jednak znamienne, że Dekret nie wspomina w ogóle o Kościołach starokatolickich, powstałych po I Soborze Watykańskim $\mathrm{w}$ rezultacie niezgody na ogłoszenie dogmatu o nieomylności doktrynalnej i prymacie jurysdykcyjnym papieża ${ }^{15}$. Z kolei podkreślanie punktów wspólnych ze Wspólnotami poreformacyjnymi, z jednoczesnym jakby wyciszaniem różnic, być może bierze się z pragmatycznego założenia, że jedynie w ten sposób można w ogóle nawiązać jakikolwiek dialog.

Jest też w soborowym Dekrecie o ekumenizmie obecna chęć jakby dodatkowego zabezpieczenia dialogu środkami spoza przestrzeni wiary, a mianowicie środkami społecznymi. Dekret z takim naciskiem podkreśla potrzebę i pożyteczność wspólnych działań na rzecz polepszania życia doczesnego w jego wymiarach społecznym, politycznym i gospodarczym, że faktycznie działania społeczne zostają uznane za narzędzie służące do osiągania jedności doktrynalnej. Jednak wskazanie na konieczność podejmowania nie tylko wysiłków na rzecz rozwoju duchowego, ale także na rzecz rozwoju społecznego jest przejściem z płaszczyzny wiary na płaszczyznę ideologii. Niewątpliwie, to $w$ tym kontekście nastąpił rozwój tak zwanej teologii wyzwolenia, wobec której Kościół katolicki musiał wielokrotnie się dystansować ${ }^{16}$. Z tego punktu widzenia patrząc, można odnieść wrażenie, że $\mathrm{w}$ jakiejś mierze ekumenizm przestał być powinnością wiary, a stał się nakazem ideologii. Tym samym jednak ujawnia się głęboki konflikt między działaniami prowadzącymi do wyzwolenia z grzechu a działaniami prowadzącymi do wyzwolenia z ucisku' ${ }^{17}$.

${ }^{14}$ Zob. T. Wojak, Ewangelik - katolik, Warszawa 1989, s. 14.

$15 \mathrm{O}$ historii i doktrynie starokatolicyzmu zob. U. Küry, Kościót starokatolicki. Historia, nauka, dążenia, tłum. W. Wysoczański [et al.], Warszawa 1996.

${ }^{16}$ Charakterystykę teologii wyzwolenia z katolickiego punktu widzenia znaleźć można w: B. Mondin, Teologowie wyzwolenia, tłum. R. Borkowski, Warszawa 1988.

17 Ireneusz Ziemiński sądzi, że jest to konflikt nieusuwalny z przyczyn teologiczno-moralnych; zob. I. Ziemiński, Kryzys chrześcijaństwa z perspektywy filozofii religii, „Filo-Sofija” 2014, nr 2(25), s. 124-126. 
4. Ukazane przykładowe niejasności, niekonsekwencje i wątpliwości uzasadniają postawienie pytania, czy jest w ogóle możliwe osiągnięcie owej jedności, której pragnie Chrystus. Na gruncie encykliki Piusa XI jest to pytanie o możliwość przyłączenia się do Kościoła katolickiego wszystkich pozostałych wspólnot chrześcijańskich; na gruncie Dekretu soborowego jest to pytanie o możliwość osiągnięcia jednolitego wspólnego rozumienia depozytu wiary. Ani w jednym, ani w drugim dokumencie nie znajdujemy wyraźnej odpowiedzi na tak postawione pytania, oba natomiast pokładają ufność w Łasce Bożej, co Dekret soborowy wyraża wprost. Jeżeli jednak osiągnięcie jedności przekracza siły ludzkie i konieczna jest interwencja Boga, to działania ekumeniczne stają się warunkiem koniecznym prośby o ową interwencję. Chodzi o wyrażenie swej woli, podjęcie wysiłków i zaufanie Bogu. $\mathrm{W}$ istocie znaczy to tyle, co wyraźne przyznanie, że jedność wszystkich chrześcijan mogłaby zostać osiągnięta jedynie w rezultacie jakiegoś niepojętego cudu. Jednak dokonanie przez Boga takiego cudu byłoby dokonaniem przemiany całej rzeczywistości ludzkiej, przekształceniem jej w rzeczywistość zbawienia; inaczej mówiąc, w rzeczywistości doczesnej nie jest to możliwe.

Sama historia zdaje się świadczyć o tym, że już w momencie swego powstania chrześcijaństwo niejako musiało rozpocząć proces dzielenia się. Dzieje religii to przecież ciągły proces powstawania nowych i instytucjonalnego dzielenia się dotychczasowych wierzeń, nie obserwujemy zaś procesu jednoczenia się poszczególnych wyznań. Jednak przyczyna takiego stanu rzeczy nie jest akcydentalna - to znaczy nie zależy tylko od uwarunkowań społecznych i politycznych generujących niezrozumienie, sprzeczności interesów i wzajemną niechęć, ale dających się przecież usunąć - lecz ma charakter zasadniczy, to znaczy inaczej być nie może. Rozumna natura człowieka sprawia, że poszukuje on coraz lepszego, pełniejszego i głębszego zrozumienia wszelkich kwestii stanowiących przedmiot jego myślenia, a więc także kwestii religijnych. A ponieważ ludzki rozum jest ograniczony, więc zawsze różni ludzie do różnych będą dochodzili twierdzeń, a niektóre $\mathrm{z}$ tych twierdzeń będą $\mathrm{w}$ tak istotnych aspektach sprzeczne z zastanym systemem wierzeń, że staną się początkiem nowego wyznania. Tak więc, dopóki wiara jest przeżywana autentycznie, rodzić będzie wyznania nowe, przez wyznania dotychczasowe uznawane za heretyckie czy schizmatyckie ${ }^{18}$. Po-

18 Jerzy Nowosielski (1923-2011), wielki malarz i głęboki myśliciel religijny, twierdzi, że człowiek, który nie tylko przeżywa swoją wiarę, ale także czyni nad nią namysł, musi mniej lub bardziej odchodzić od jej oficjalnej interpretacji. „Każdy człowiek o autentycznych intuicjach religijnych musi być heretykiem, gdyż herezja to jest inny pogląd, to jest dialog wewnętrzny, to jest walka z zastanymi formami naszej świadomości, które odziedziczyliśmy albo 
glądy sprzeczne z ortodoksją przestaną się pojawiać albo wtedy, gdy sama ortodoksja stanie się nieważna, czyli wiara zaniknie, albo wtedy, gdy człowiek pozna samą Prawdę, czyli w rzeczywistości zbawienia. Ograniczoność ludzkiego rozumu sprawia więc, że wyznanie, którego członkowie autentycznie przeżywają swoją wiarę, nie może trwać w jedności.

Nawet jednak przy założeniu, że ten proces dzielenia się wyznań ma swój kres, nie jest możliwe, aby rozpoczął się proces odwrotny, czyli łączenie się poszczególnych wyznań w jedno. O tym, że osiągnięcie jedności chrześcijan w sposób wskazany w encyklice Piusa XI, czyli przez powrót na łono Kościoła katolickiego, jest niemożliwe, również przesądza sama natura ludzka. W rzeczywistości skażonej grzechem pierworodnym ludzka natura sprawia, że ludzie pozostają wobec siebie nieufni, czują się bezpieczniej wewnątrz jakiejś grupy, która ich spaja. Jedność urzeczywistniana jest więc w ramach rodziny, narodu, państwa, organizacji społecznej czy politycznej, w związkach przyjacielskich itp., przy czym ułomność ludzka sprawia, że nigdy nie jest to jedność wolna od wewnętrznych napięć i ujawniających się różnic, prowadzących bardzo często do konfliktów. W realnym świecie doczesnym po prostu nie jest możliwe urzeczywistnienie jedności całego rodzaju ludzkiego; doświadczenie historyczne wskazuje, że wszelkie próby tworzenia takiej jedności metodami perswazyjnymi kończyły się fiaskiem, a realizowane $\mathrm{z}$ zastosowaniem siły kończyły się tragicznie. Jest to konsekwencją struktury bytowej tego świata kształtującej sposób naszego myślenia o nim. Człowiek nie może ujmować rzeczywistości inaczej, jak poprzez pojęcia dualne. Nie ma plusa bez minusa, nie mielibyśmy pojęcia dnia, gdyby nie istniała noc, istnienie góry i doliny warunkują się wzajemnie. To dlatego mam moją rodzinę, ponieważ istnieją inne rodziny, należę do mojego narodu lub państwa, ponieważ istnieją inne narody lub państwa, jestem członkiem tej organizacji, ponieważ istnieją także inne organizacje itp. Myślenie w kategoriach: ,ja - ty”, ,"mój - twój”, , swój - obcy” i podobnych jest warunkiem koniecznym bycia świadomym własnej tożsamości jednostkowej i grupowej ${ }^{19}$. Spróbujmy wyobrazić sobie, że oto wszyscy chrześcijanie two-

w inny sposób przyjęliśmy, i jesteśmy zmuszeni do ich zweryfikowania"; J. Nowosielski, Sztuka po końcu świata. Rozmowy, Kraków 2012, s. 364. Por. ibidem, s. 401.

${ }^{19}$ Ideologiczna presja tak zwanej poprawności politycznej dlatego jest tak bardzo niebezpieczna, że usiłując zlikwidować wszystko, co różnicuje, jako czynniki szkodliwe, niszczy poczucie tożsamości narodowej, kulturowej, cywilizacyjnej, płciowej itd. Kwalifikując wszelkie zachowania oparte na naturalnym poczuciu własnej tożsamości i odrębności jako "rasizm", "ksenofobię", „szowinizm”, „seksizm” itp., prowadzi do zastąpienia wspólnoty zbiorem zatomizowanych jednostek. Jakiś minimalny dystans wobec "obcego" czy „innego" jest warunkiem koniecznym istnienia odrębnych wspólnot ludzkich; szerzej na ten temat zob. Z. Musiał, 
rzą jedność; w rzeczywistości naszego doświadczenia znaczyłoby to, że wspólnota chrześcijańska może być przez nas w ogóle pojmowana dzięki istnieniu wspólnot niechrześcijańskich. A gdyby już wszyscy nawrócili się na chrześcijaństwo? Wówczas wprawdzie mogliby pojmować samych siebie jako wspólnotę chrześcijańską poprzez odniesienie do Chrystusa, ale zarazem nadal musieliby określać samych siebie poprzez opozycję względem jakiejś innej wspólnoty, np. anielskiej.

Ukazany przez papieża Piusa XI wzorzec ekumenizmu jako ruchu w kierunku jedynego Kościoła - mianowicie katolickiego, ale także (dodajmy) jakiegokolwiek innego - jest więc niemożliwy do zrealizowania, gdyż zawiera w sobie sprzeczność: rozszerzanie danej wspólnoty na wszystkich ludzi prowadzić musiałoby ostatecznie do jej likwidacji. Wyrażone przez Jezusa pragnienie, ",aby wszyscy byli jedno", nie może zatem zrealizować się w rzeczywistości przyrodzonej i dopiero w rzeczywistości zbawienia może się urzeczywistnić. Zważmy jednak, że jak podaje Pismo Święte, nawet wspólnota anielska podzieliła się. Ludzka świadomość tożsamości grupowej warunkowana jest świadomością, że istnieją inne grupy; i jest tak silna, że przenoszona zostaje $\mathrm{w}$ rzeczywistość nadprzyrodzoną. Wielu, może nawet większość, ludzi wielkiej i mocnej wiary przyjmuje jako oczywistość, że społeczność zbawionych istnieć będzie w opozycji do społeczności potępionych, i widzi w tym realizację sprawiedliwości Bożej. A co bardziej znamienne wielu z nich przyjmuje, że radość zbawionych wzmacniana będzie rozpaczą potępionych. Katolicki filozof Blaise Pascal (1623-1662) sądził nawet, że sam Bóg będzie śmiał się i szydził z potępionych ${ }^{20}$. Protestancki teolog Jonathan Edwards (1703-1758) uzasadniał, że wieczne męki potępionych potęgować będą wieczną radość zbawionych ${ }^{21}$. Teza o wiecznych mękach ludzi potępionych ma podstawy w Ewangelii22; przekonanie, że wieczna radość zbawionych może brać się także z wiecznej rozpaczy potępionych, ma podstawy tylko w naszej ludzkiej naturze. Zrozumiałe jest więc pragnienie, by

B. Wolniewicz, Ksenofobia i wspólnota. Przyczynek do filozofii człowieka, Komorów 2010, s. 17 i nast.

20 „Czyż nie widzimy bowiem, iż Bóg wraz nienawidzi grzeszników i gardzi nimi, tak dalece, iż nawet w godzinę ich śmierci, wówczas gdy stan ich najbardziej jest smutny i opłakany, sprawiedliwość boska przyda drwinę i szyderstwo do pomsty i wściekłości, która skaże ich na wiekuiste męki [...]. I święci, ożywieni tym samym duchem, poczną sobie tak samo"; B. Pascal, Prowincjałki, tłum. T. Żeleński-Boy, Warszawa 1963, s. 175.

21 ,Jestem przekonany, że męki piekielne będą wieczne ze względu na jedno wielkie dobro, jakie Bóg zamierza przez nie w swojej mądrości, czyli to, że ich widok będzie potęgować szczęście, miłość i radosne dziękczynienie aniołów i ludzi, którzy są zbawieni - do czego widok ów nader dobrze skłania"; J. Edwards, Wybór pism, tłum. M. Choiński, P. Kwiatkowski, Z. Sierotnik, Wrocław 2014, s. 83. Por. ibidem, s. 132-133.

22 Zob. Mt 24,51; 25,41. 
w rzeczywistości przemienionej została przemieniona także ludzka natura. Ale czy jest rozsądne utrzymywać, że wprawdzie w rzeczywistości doczesnej nie spełni się pragnienie, by wszyscy ludzie stali się jednością $\mathrm{w}$ ramach jednego Kościoła, ale w rzeczywistości wiecznej spełni się nadzieja, że wszyscy zostaną zbawieni?

5. Niemożliwy do urzeczywistnienia jest także wzorzec ukazany w soborowym Dekrecie o ekumenizmie. $W$ tym wypadku jednak nie jest tak z powodu jedynie uwarunkowań ludzkiej natury, lecz przyczyną zasadniczą jest natura Wszechświata. Rzeczywistość przyrodnicza działa zgodnie ze stałymi prawami, które odkrywa i opisuje fizyka. Jednym z działów fizyki jest termodynamika opisująca przemiany energii $\mathrm{w}$ zjawiskach na poziomie ciał, bez wnikania $\mathrm{w}$ ich strukturę atomową; jednym $\mathrm{z}$ podstawowych praw fizyki jest druga zasada termodynamiki ${ }^{23}$. Szczególne znaczenie tej zasady na tym polega, że określa ona kierunek procesów zachodzących $\mathrm{w}$ świecie przyrody. Najprościej rzecz ujmując, druga zasada termodynamiki głosi, że ciepło przekazywane jest od ciał ciepłych do zimnych, a nie odwrotnie. $\mathrm{W}$ sformułowaniu tej zasady wykorzystuje się pojęcie entropii ${ }^{24}$. Entropia to funkcja stanu określająca kierunek przebiegu procesów spontanicznych w układzie izolowanym. Zapewne większość z nas obserwuje na co dzień wzrost entropii, gdy wlewa śmietankę do filiżanki z gorącą kawą - najpierw entropia jest mała, śmietanka oddziela się pasmem bieli od czerni kawy, ale po kilku chwilach oba płyny mieszają się całkowicie i zawartość filiżanki przybiera barwę brązową, a ich temperatury wyrównują się. Fizycy pojmują ciepło jako miarę nieporządku - temperatura ciała jest miarą intensywności chaotycznych ruchów cieplnych tworzących to ciało atomów lub cząstek, entropia zaś jest miarą chaotyczności, czyli nieuporządkowania tych ruchów. Mówiąc najprościej - im większy chaos, czyli im mniejsze uporządkowanie, tym większa entropia. Możemy więc drugą zasadę termodynamiki sformułować następująco: w układzie izolowanym $\mathrm{w}$ dowolnym procesie entropia nigdy nie maleje. Inaczej, w układzie izolowanym mogą zachodzić tylko takie procesy, w wyniku których entropia układu wzrasta lub co najwyżej pozostaje stała. Ponieważ poza Wszechświatem nic nie istnieje, więc jest on niejako z definicji układem izolowanym, zatem zgodnie $\mathrm{z}$ drugą zasadą termodynamiki we Wszechświecie entropia musi wzrastać. Inaczej mówiąc, we Wszechświecie przejawia się stała dążność do równomiernego

${ }_{23}$ Zob. np. L.N. Cooper, Istota i struktura fizyki, tłum. J. Kozubowski, Warszawa 1975, s. $349-401$.

${ }^{24}$ Nazwę „entropia” (od greckiego słowa „przekształcać”) wprowadził niemiecki fizyk Rudolf Clausius (1822-1888). 
rozproszenia energii cieplnej, do zatarcia różnic temperatury między częściami układu.

Dopóki istnieją nierówności energii, elementy Wszechświata ścierają się ze sobą, zwalczają się, a tym samym Wszechświat niejako żyje, zmienia się co do istniejących w nim układów i powiązań. Jednak nieusuwalna tendencja do wyrównywania różnic, do zrównania poziomów energetycznych musi w końcu doprowadzić do wyrównania całkowitego. Fizyk tak pisze o działaniu drugiej zasady termodynamiki: „Zastosowanie tej zasady do Wszechświata jako całości wyznacza kierunek biegu wszystkich procesów fizycznych. Wzrost entropii oznacza, że ciała gorące dążą do oziębienia się, a ciała zimne do ogrzania [...], aż wreszcie cały Wszechświat osiągnie swoją letnią, jednakową wszędzie temperaturę - entropia osiągnie maksimum i to już koniec, nic więcej nie będzie mogło się zdarzyć" 25 . Czas, w którym się to dokona, fizycy wyliczają w miliardach lat, niemniej jednak ostateczną postacią Wszechświata będzie całkowity bezwład i martwota.

Przygnębiająca wizja śmierci cieplnej Wszechświata rodzi niepokój, że być może taki sam będzie kres każdego ludzkiego tworu duchowego - każdej kultury, cywilizacji, religii itp. Przecież rzeczywistość kulturowa wyrasta na bazie rzeczywistości przyrodniczej, a zatem zasadne jest domniemanie, że również w świecie kultury obowiązuje duchowy odpowiednik drugiej zasady termodynamiki. Powstały teorie wyjaśniające działaniem prawa entropii przebieg dziejów ${ }^{26}$ czy rozwój gospodarczy ${ }^{27}$. Zauważono, że prawo entropii umożliwia wyjaśnienie idei dekadencji kulturowej28. Zasadne jest więc uznanie, że w rzeczywistości społecznej działa siła dążąca do wyrównania wszelkich nierówności między ludźmi, czyli siła będąca odpowiedni-

${ }^{25}$ L.N. Cooper, op. cit., s. 376.

26 Amerykański historyk Henry Adams (1838-1918) przedstawił propozycję uprawiania historii jako nauki w kontekście drugiej zasady termodynamiki (zob. H. Adams, A Letter to American Teachers of History, Washington 1910). Adams odwoływał się do wcześniej wyrażanych podobnych poglądów, m.in. cytował filozofa Eduarda von Hartmanna (1842-1906), który wskazywał, że w badaniach nad społeczeństwem nieświadomie przyjmuje się, że pierwsza zasada termodynamiki gwarantuje stałą sumę energii społecznej, a zapomina się, że zgodnie $z$ drugą zasadą termodynamiki ta energia musi rozpraszać się (zob. ibidem, s. 20-21). Pierwsza zasada termodynamiki opisuje prawo zachowania energii dla układów termodynamicznych.

${ }^{27}$ Amerykański ekonomista Nicholas Georgescu-Roegen (1906-1994) ujął przestrzeń działań gospodarczych jako wielki system termodynamiczny, w którym nieuchronnie wzrasta entropia, a zasoby materialne ulegają rozproszeniu; zob. N. Georgescu-Roegen, The Entropy Law and the Economic Process, Cambridge 1971; zob. także: idem, Entropia, wartość i rozwój, [w:] Ponad ekonomia, wybór i tłum. J. Grosfeld, Warszawa 1985.

28 „Idei, która związana była z rozczarowaniem społeczeństwa nie dążącego już dłużej do perfekcji, lecz staczającego się ku miernocie - kulturze z telewizją lecz bez geniuszy, architekturze podmiejskiej wygody, ale bez Notre Dame" (L.N. Cooper, op. cit., s. 366). Jest znamienne, że powyższe słowa wypowiedział fizyk. 
kiem tej, którą w świecie rzeczywistości przyrodniczej opisuje druga zasada termodynamiki.

Najsilniejszym przejawem działania tej siły jest ideologia socjalistyczna, szczególnie jej skrajna odmiana, czyli komunizm. Niemiecki filozof kultury i historiozof Oswald Spengler (1880-1936), autor dzieła Zmierzch Zachodu, którego pierwszy tom ukazał się w 1917 roku, nie odwoływał się do fizyki i pozostawał w kręgu pojęć humanistyki, twierdził jednak, że dążenia egalitarne są bardzo mocno zakorzenione w moralności zachodniej, a praktycznym zastosowaniem tej postawy wobec świata jest doktryna socjalizmu29. Socjalizm nie jest przez Spenglera rozumiany jako tylko doktryna ekonomiczna, lecz jako system etyczny - jako etyczny monoteizm postulujący zlikwidowanie wszelkich nierówności między ludźmi i przekształcenie rzeczywistości społecznej wedle jednolitego wzorca $^{30}$.

$\mathrm{Na}$ stanowisko Spenglera powoływał się Marian Zdziechowski (1861-1938), filozof mający bardzo pesymistyczną wizję świata zmierzającego ku zagładzie. Szczególny wpływ na jego postrzeganie rzeczywistości kulturowej wywarły osobiste doświadczenia wyniesione z rewolucji bolszewickiej, pod wpływem których umocnił się w przekonaniu, że komunizm, czyli skrajna odmiana socjalizmu, jest jedną z najważniejszych oznak kryzysu kultury europejskiej31. Widział $\mathrm{w}$ komunizmie emanację siły niszczącej wszelką kulturę ${ }^{32}$. Potwierdzenie swojego stanowiska znalazł Zdziechowski w wyjaśnieniu tendencji socjalistycznych działaniem drugiej zasady termodynamiki i prawa entropii - wyjaśnieniu, które podał Ryszard Świętochowski (1882-1941) w rozprawie Zanik energii społecznej w świetle fizyki, wydanej w 1921 roku $^{33}$. Wedle Świętochowskiego, stała skłonność socjalistów do zaprowadzenia w szczególny sposób pojętej zasady sprawiedliwości jest

29 "Wszyscy naprawiacze świata są socjalistami”; O. Spengler, Zmierzch Zachodu. Zarys morfologii historii uniwersalnej, tłum. J. Marzęcki, Warszawa 2001, s. 210.

30 Zdaniem Spenglera, skłonność do takich działań jest głęboko zakorzeniona w naturze ludzkiej: „Wszyscy jesteśmy socjalistami, czy tego świadomie chcemy, czy też nie”; ibidem, s. 219; por. ibidem, s. 209.

31 Zob. M. Zdziechowski, Wybór pism, Kraków 1993, w szczególności teksty: Koniec Europy, Jak upadaja cywilizacje, Tragiczna Europa, Duchowa podstawa walki z bolszewizmem i Widmo przyszłości (s. 407-465 i 515-532). Drugi i trzeci z tych tekstów przedrukowane w: Katastrofizm okresu międzywojennego, wybór A. Kołakowski, Warszawa 2014, s. 63-89.

32 "Jest to zło jako negacja wszystkiego, co nas w górę, ponad szarzyznę powszedniości, ponad zmienność i znikomość unosi - tego, co my wyrazami Bóg, boskość, duch, dusza, dobro, piękno, miłość, litość, nieśmiertelność itd. określamy"; M. Zdziechowski, op. cit., s. 522-523.

33 Zob. R. Świętochowski, Zanik energii społecznej w świetle fizyki, Warszawa - Poznań - Torun 1921; przedrukowane w: Katastrofizm okresu międzywojennego, op. cit., s. 29-61. Ryszard Świętochowski był synem Aleksandra Świętochowskiego (1849-1938), pisarza, publicysty, działacza społecznego, jednego z najwybitniejszych przedstawicieli polskiego pozytywizmu. 
w rzeczywistości ludzkiej odpowiednikiem zasady wzrostu entropii w rzeczywistości przyrodniczej. $\mathrm{W}$ istocie bowiem walka $\mathrm{z}$ wszelką nierównością społeczną i indywidualną jest tym, czym w przyrodzie działanie sił prowadzących do wyrównywania poziomów energetycznych. Dlatego socjalizm eliminując napięcia społeczne i międzyludzkie zmniejszające entropię, hamuje rozwój i prowadzi do zastoju ${ }^{34}$.

Wzrost entropii realizuje się więc i w sferze przyrodniczej, i w sferze kulturowej. Ale jak w przyrodzie działają moce przeciwstawiające się wyrównywaniu potencjałów, tak w kulturze ujawniają się siły sprzeciwiające się egalitaryzmowi. Dzięki temu zarówno we Wszechświecie, jak i w świecie kultury entropia jeszcze dalece nie osiągnęła poziomu maksymalnego. Przyrodnicy uzasadniają, że Wszechświat musi w końcu dojść do stanu maksymalnej entropii; czy jest to też nieuniknione w sferze ludzkiej duchowości? Skłonność do zrównywania poziomów zdaje się trwałym czynnikiem ludzkiej natury, choć z drugiej strony równie naturalnym czynnikiem zdaje się chęć wybicia się ponad innych. Można by więc w pewnym uproszczeniu powiedzieć, że w sferze ludzkiej kultury entropia osiągnie poziom maksymalny, gdy siła tych, którzy chcą innych zniżyć do swego poziomu, trwale przewyższy siłę tych, którzy chcą wybijać się ponad zastany poziom. Doświadczenie uczy, że tych pierwszych jest więcej, aczkolwiek trudno byłoby wskazać, jaka ich liczebność powinna zostać uznana za przesądzającą o stałej niemożliwości czasowego zmniejszania entropii.

Spójrzmy więc $\mathrm{z}$ tego punktu widzenia na program ekumenizmu wyrażony w Dekrecie Unitatis redintegratio. Jeżeli potraktujemy chrześcijaństwo jako układ izolowany, to odniesiemy wrażenie, że autorzy Dekretu proponują działania prowadzące do ciągłego zwiększania jego entropii. Dotyczy to zarówno postulowanych działań i zachowań międzyludzkich, jak i dialogu teologicznego, ale także działań instytucjonalnych. W sferze kontaktów międzyludzkich Dekret zaleca powstrzymywanie się od wyrażania opinii fałszywych czy choćby nieżyczliwych wobec „braci odłączonych”. Pomińmy

34 „Zniknie współzawodnictwo, chęć dorobku, użycia, nastąpi upaństwowienie powszechne. Ani miłość, ani własność, ani zawiść, ani aktywność, ani pragnienie zabezpieczenia siebie i potomstwa nie będzie miało pola do walki, do wielkich przegranych i wielkich zwycięstw. Nastąpi spokój. Zamiast różnicy poziomów, zamiast olbrzymiego wodospadu energii [...] nastąpi cicha, nieuchronna, spokojna powierzchnia jednolitego stanu" (ibidem, s. 50). R. Świętochowski przewidywał, że trwała realizacja doktryny komunistycznej postępowałaby kolejno przez wprowadzenie egalitaryzmu społecznego, następnie zlikwidowanie różnic intelektualnych między jednostkami, potem ujednolicenie jednostkowych typów ludzkich, wreszcie przyznanie równych praw ludziom i zwierzętom. Zwróćmy uwagę, że swoistą mutacją komunizmu są współczesne ideologie postulujące zrównanie kultur, skłonności seksualnych czy umożliwienie swobodnego wyboru płci. Por. wyżej, przypis 21. 
kwestię, że taka postawa powinna cechować każdego człowieka z racji zwykłej ludzkiej przyzwoitości, a chrześcijanina nadto z uwagi na zalecenia ewangeliczne, nie zaś ze względu na skuteczność działań ekumenicznych. Zwróćmy natomiast uwagę na zależność między stopniem wzajemnej tolerancji i życzliwości a stopniem akceptacji dogmatów wiary. Katolik i prawosławny łatwiej nawiążą i utrzymają przyjazne kontakty, jeśli na przykład kwestia, czy Duch Święty pochodzi „od Ojca i Syna”, czy „od Ojca”, nie będzie przez nich uznawana za istotną lub w ogóle nie będzie przedmiotem ich zainteresowania; podobnie jeśli chodzi o stanowisko luteranina i katolika w kwestii usprawiedliwienia przez wiarę czy także przez uczynki. Jedność w przestrzeni kontaktów międzyludzkich będzie więc tym mocniejsza, im bardziej wiara pozbawiona zostanie swego wymiaru dogmatycznego. Najpełniejsza jedność byłaby w sytuacji wiary letniej, w stanie religijnej obojętności, czyli w stanie bardzo wysokiej entropii.

Dekret postuluje jednocześnie konieczność stałej przemiany duchowej, wyrobienie $\mathrm{w}$ sobie gotowości do otwierania się w duchu miłości na drugiego człowieka, niezależnie od tego, jakiego jest on wyznania. Wyrażać się to ma prowadzeniem życia zgodnie $\mathrm{z}$ zasadami ewangelicznymi, przede wszystkim zgodnie z zasadą miłości bliźniego. Otóż niewątpliwie położenie nacisku na dawanie świadectwa wiary poprzez życie zgodne z ewangelicznymi zasadami moralnymi musi prowadzić do przekonania, że różnice dogmatyczne są nieistotne dla zbawienia. Tym samym jednak Dobra Nowina o zbawieniu przekształcona zostałaby w system etyczny, w zbiór nakazów i zakazów moralnych ${ }^{35}$. Pełna jedność chrześcijan jako jednostek ludzkich dokonałaby się więc w sytuacji zniesienia chrześcijaństwa jako religii. Skoro Dekret soborowy zaleca wspólne działania na rzecz zmniejszania głodu, biedy, chorób, zacofania i nierówności społecznych oraz na rzecz utrzymania pokoju, to można sobie wyobrazić, że chrześcijaństwo w stanie marazmu wiary, czyli w stanie dużego poziomu entropii, zastąpione zostałoby rodzajem religijnego socjalizmu, który jako system rozpocząłby swój własny proces zwiększania entropii.

W analogiczny sposób do zwiększania entropii chrześcijaństwa prowadzić musi realizacja zaleceń Dekretu skierowanych do teologów. Prowadzenie dialogu na gruncie teologii dogmatycznej sprowadza się przecież do usiłowań wypracowania wspólnego rozumienia dogmatów, czyli w istocie

35 Proces taki rzeczywiście postępuje w Kościele katolickim. Zwraca na to uwagę I. Ziemiński, interpretując ten fakt jako oznakę kryzysu (zob. I. Ziemiński, op. cit., s. 121-123). O dominacji etyki w nauczaniu Karola Wojtyły (także jako papieża Jana Pawła II) zob. T. Bartoś, Etyka wedtug Karola Wojtyły, „Kwartalnik Filozoficzny” 2005, nr 4, t. XXXIII, s. 195-223. 
mamy tu założenie, że różnice dogmatyczne - wyznaczające wszak tożsamość poszczególnych Kościołów i Wspólnot wyznaniowych - są rezultatem błędów, niewłaściwej interpretacji czy nieporozumień i jako takie powinny być usunięte. Załóżmy, że te działania są skuteczne i stopniowo znikają kolejne różnice dogmatyczne, aż wreszcie ustalone zostaje jedno, powszechnie przyjęte rozumienie. Byłoby to oczywiście tożsame ze zlikwidowaniem odrębnych Kościołów i Wspólnot i z powstaniem jednego Kościoła. Jednak skoro w takim Kościele sposób rozumienia treści dogmatycznych byłby jeden i jednolity - $\mathrm{w}$ tym przynajmniej sensie, że wszelkie różnice nie miałyby istotnego znaczenia - to obniżeniu i jakby spłaszczeniu musi ulec poziom i napięcie teologicznych dyskusji ${ }^{36}$. Ewentualne spory i kontrowersje teologiczne muszą coraz bardziej wyciszać się aż do całkowitego zaniku, czyli do osiągnięcia przez chrześcijaństwo stanu maksymalnego poziomu entropii. W tym kontekście także kwestia prymatu papieskiego może zaniknąć tylko wtedy, gdy już wszyscy będą równi, co jest oczywiście możliwe pod warunkiem, że problem stanie się obojętny zarówno dla świeckich, jak i dla kapłanów; a stan pełnej obojętności to stan pełnej entropii.

Tak więc gdyby jedność chrześcijaństwa zrealizowana została dzięki działaniom zalecanym przez Dekret Unitatis redintegratio, to chrześcijaństwo osiągnęłoby stan religijnej obojętności i bezruchu, czyli stan, w którym entropia układu jest maksymalna. Można wierzyć, że pełna jedność chrześcijan osiągnięta zostanie w rzeczywistości zbawienia ${ }^{37}$. Jednak twierdzić, że może być ona zrealizowana w rzeczywistości doczesnej, to tyle co uznać, że polegać ona będzie na zlikwidowaniu chrześcijaństwa jako religii, gdyż chrześcijaństwo wejdzie w stan maksymalnej entropii. Fizycy twierdzą, że wszystkie siły, które teraz zapobiegają równomiernemu rozkładaniu się energii, kiedyś w końcu zanikną i Wszechświat osiągnie stan pełnej entropii, czyli całkowitego bezwładu i martwoty. Można więc zakładać, że to samo czeka każdą religię. Myśl taka nie jest obca niektórym wierzeniom. Buddyści dążą do nirwany, czyli nieuwarunkowanego stanu, który jest wprawdzie rzeczywisty, ale w którym nie zachodzą żadne zmiany w poziomach energii; można to uznać za stan pełnej entropii duchowej. W mitologii greckiej znajdujemy opowieść o pięknym młodzieńcu Endymionie, któremu bogowie dali to, co

36 Jak już zostało wskazane, namysł nad własną wiarą musi prowadzić do różnicy zdań; zob. wyżej, przypis 20.

37 Pewną zmianę akcentów wprowadza w rozważaną kwestię encyklika Jana Pawła II Ut unum sint wydana 25 maja 1995 roku. Zob. Jan Paweł II, Ut unum sint - O działalności ekumenicznej, [w:] Encykliki Ojca Świętego Jana Pawła II, Kraków 1996, s. 991-1077. To zagadnienie wymaga jednak odrębnego rozważenia. 
mają najlepszego dla ludzi - wieczny sen; wieczny sen także można interpretować jako stan pełnej entropii. Nie będzie zatem bezzasadne przypuszczenie, że być może największym dobrem, jakie człowiek może osiągnąć, jest stan całkowitej entropii. Tylko dlaczego wolimy wierzyć, iż stan zbawienia nie będzie stanem pełnej entropii, tylko stanem świadomego doznawania szczęścia?

\section{Konkluzja}

Jedność chrześcijaństwa to idea nieosiągalna w rzeczywistości doczesnej, gdyż dążenie do jej realizacji prowadzi $\mathrm{w}$ istocie do zniesienia chrześcijaństwa. Urzeczywistnienie tej jedności w odniesieniu do samych chrześcijan wedle wzorca $\mathrm{z}$ encykliki Piusa XI jest wprawdzie teoretycznie możliwe, lecz późniejsze trwałe utrzymanie tego stanu byłoby możliwe tylko za cenę zaniku intuicji religijnych; urzeczywistnienie jej w odniesieniu do wszystkich ludzi byłoby zaś utratą tożsamości chrześcijan jako jednostek i chrześcijaństwa jako religii. Urzeczywistnienie jedności wedle wzorca soborowego Dekretu musiałoby doprowadzić chrześcijaństwo i chrześcijan do stanu całkowitej apatii. Jednoznaczne stanowisko Piusa XI zdaje się oparte nie tylko na mocnym przekonaniu o własnej słuszności, ale także na trzeźwej ocenie natury ludzkiej. Nieco rozmyte i niejednoznaczne stanowisko wyrażone w soborowym Dekrecie jest wyrazem utopijnego marzenia i dlatego można by je określić jako religijny socjalizm. W odróżnieniu od socjalizmu społecznego, nie ma on obecnie siły zdolnej niszczyć zastany porządek i może jedynie osłabiać sam siebie. To prawda, że chrześcijanie współcześni, w odróżnieniu od chrześcijan dawnych wieków, gdy już mordują się wzajemnie, to tylko z rzadka odwołują się do swego wyznania, a poszczególne Kościoły i Wspólnoty chrześcijańskie wojnę zastąpiły dialogiem, wprawdzie do niczego nie prowadzącym, ale kształtującym zasady przyzwoitego traktowania się nawzajem. Jednak ten osobliwy międzywyznaniowy savoir-vivre nie jest możliwy dzięki zwiększającej się jedności, lecz bierze się z osłabienia wiary, ze wzrostu poziomu religijnej obojętności. Przecież wyznanie żywe i dynamiczne mocą wiary swych wyznawców bynajmniej nie jest tolerancyjne. Najwyższe dobro nie będzie dane człowiekowi w życiu doczesnym, więc należy porzucić marzenia o jedności wszystkich chrześcijan i zaprzestać podejmowania beznadziejnych działań, by ją osiągnąć. Bardziej pożyteczny jest namysł nad przyczynami kryzysu wiary. 


\section{Unattainable Unity or Two Models of Ecumenism}

\section{Summary}

The term ecumenism is used to refer to initiatives aimed at uniting all Christians into one common Church. The ecumenical movement originated at the beginning of the 19th century in Protestant and Anglican Churches. At that time the Catholic Church believed it to be the result of misguided understanding of theological concepts. This early attitude of the Catholic Church was expressed by Pope Pius XI in his 1928 encyclical Mortalium animos. The major change of attitude came with the Second Vatican Council: the 1964 Decree on ecumenism Unitatis redintegratio brought a new interpretation of the concept, an interpretation which may seem contradictory to the previous one. This paper argues that the two documents are not in fact contradictory, but present two models of ecumenism. However, neither of them can be implemented. This impossibility cannot be avoided because it is inherent in the metaphysical nature of this world and the nature of man who belongs to it. 